\title{
Virus Zika, una nueva epidemia en puerta
}

Se conoce coloquialmente como Zika a la enfermedad ocasionada por el virus Zika (ZIKV), un arbovirus (virus transmitidos por artrópodos) perteneciente al género Flavivirus, de la familia Flaviviridae. Análisis genéticos y moleculares han demostrado que existen dos grandes linajes de ZIKV, el africano y el asiático (1).

La fiebre producida por ZIKV es considerada una enfermedad emergente en distintos países del continente americano. Es originaria de África y Asia. Este virus pertenece a la misma familia de los virus Dengue (DENV), Fiebre Amarilla (YFV), Encefalitis Japonesa (JEV) y Nilo Occidental (WNV) (2).

ZIKV se identificó por primera vez en 1947 en Uganda (África), específicamente en los bosques de Zika. Se descubrió en un mono Rhesus cuando se realizaba un estudio sobre la circulación de fiebre amarilla en ambientes selváticos. Posteriormente en 1952, aparecieron los primeros reportes serológicos en seres humanos de Uganda y Tanzania; sin embargo, no fue hasta 1968 cuando se logró aislar al virus por primera vez en muestras provenientes de pacientes que radicaban en Nigeria. En el año 2007, tuvo lugar el primer brote importante en la Isla de Yap (Micronesia), en el cual se notificaron 185 casos sospechosos, de los cuales se confirmaron 49; dicho brote se prolongó durante 13 semanas (de abril a julio). En febrero de 2014, las autoridades sanitarias de Chile confirmaron un caso de transmisión autóctona de infección por ZIKV en la Isla de Pascua; mismo que coincidió con otros focos de transmisión en islas del Pacífico: Polinesia Francesa, Nueva Caledonia e Islas Cook. En el año 2015, en Brasil se presentaron los primeros casos autóctonos de la enfermedad; en noviembre de ése mismo año, la Secretaría de Salud (SSA) de México, reportó el primer caso de ZIKV importado en un viajero procedente de Santa Martha, Colombia (2).

El problema más serio es que la transmisión se da principalmente por mosquitos vectores pertenecientes a la familia Cuilicidae y al género Aedes. La transmisión se presenta en ciclos urbanos y silvestres, según los mosquitos vectores involucrados. Así, Aedes aegypti está relacionado en la transmisión urbana. Otras especies reportadas como vectores son Aedes polynesiensis y Aedes albopictus. El vector Aedes hensilli fue identificado como responsable del brote en la Isla de Yap (2007). El virus ingresa al organismo del hospedero susceptible durante el proceso de alimentación de dichos insectos vectores hembras.

Aún no se ha identificado un reservorio de la enfermedad; sin embargo, se sugiere que es un primate, posiblemente, el mismo ser humano. Se han identificado anticuerpos anti-Zika en mamíferos grandes como orangutanes, cebras y elefantes, además de pequeños roedores.

La evidencia de la emergencia de casos por infección por ZIKV fuera de sus áreas originales (endémicas) con brotes en distintas regiones del mundo, demuestran la potencialidad de este arbovirus para propagarse por países en los que circulan artrópodos vectores potenciales como ocurre en gran parte del territorio nacional, donde se ha documentado la presencia de Aedes aegypti y Aedes albopictus, o por infección de personas al viajar a los países con esa enfermedad. En México, la SSA reportó el primer caso de Zika en un joven de 26 años de edad, originario de Querétaro, quien a su regreso de Colombia -donde ya se han detectado casos de Zika- presentó los síntomas, según explicó el subsecretario de Prevención y Promoción de la Salud, Pablo Kuri (3).

Una considerable proporción de individuos afectados desarrollará una infección asintomática 
Torres-Castro, et al

o sub-clínica; no obstante, los pacientes que presenten la forma clínica de la enfermedad, desarrollarán signos clínicos muy similares a otras infecciones por arbovirus como DENV y Chikungunya.

Los síntomas aparecen posterior al periodo de incubación que suele oscilar entre los 3 y 12 días posteriores a la picada del vector infectado. La infección por ZIKV se manifiesta generalmente en: artralgia, edema en extremidades, fiebre moderada, cefalea, dolor retro orbital, hiperemia conjuntival, exantemas, prurito, vértigo, mialgia y desórdenes alimenticios (4). La infección no ocasiona mortalidad, no obstante se ha observado un aumento en los casos de microcefalia en Brasil, que pudieran estar causada por el VIKZ, este aumento de malformaciones sería un desastre nacional, sino se actúa de manera coordina, a tiempo y con inteligencia (4-6).

No existe tratamiento antiviral o vacuna específica para la infección por ZIKV. Lo recomendable es el tratamiento sintomático posterior a la exclusión de enfermedades más graves como la malaria, el dengue y otras infecciones producidas por bacterias. Resulta importante diferenciar la fiebre por ZIKV de otras como el dengue, debido al peor pronóstico clínico de dengue. Sin embargo, dada la similitud clínica esto parece muy difícil clínicamente (4).

La prevención es la única manera de evitar la picadura de los mosquitos Aedes, mismos que trasmiten DENV y Chikungunya, por lo tanto, el trabajo coordinado entre autoridades de la SSA estatal, municipal y la comunidad debe de ser obligatoria, para lograr la erradicación de las tres virosis que son trasmitidas por el mismo mosquito.

Marco Antonio Torres-Castro

Fernando I. Puerto

Laboratorio de Enfermedades Emergentes y Reemergentes, Centro de Investigaciones Regionales "Dr. Hideyo Noguchi”, Universidad Autónoma de Yucatán. Mérida, Yucatán, México.

\section{REFERENCIAS}

1. Rodríguez-Morales AJ. Zika: the new arbovirus threat for Latin America. J Infect Dev Ctries. 2015;9(6):684-685.

2. Ioos S, Mallet HP, Leparc Goffart I, Gauthier V, Cardoso T, Herida M. Current Zika virus epidemiology and recent epidemics. Med Mal Infect. 2014;44(7):302-307.

3. Cruz-Marínez A. Llega a México de Colombia el primer caso de Zika en México. La Jornada 2015 nov 12. En linea Primera página, una sola columna. (Consultado el 6 de enero de 2016). Disponible en URL: http://www.jornada. unam.mx/ultimas/2015/11/17/llega-a-mexicoprimer-caso-de-virus-de-zika-procedente-decolombia-1008.html

4. Editorial. El virus zika y la epidemia de microcefalia en bebés que no tiene precedentes en el mundo. BBC Mundo 2015 nov 13 (en línea). Primera página investigación BBC. (Consultado 8 de enero de 2016). Disponible en URL: http://www.bbc.com/ mundo/noticias/2015/11/151130_brasil_ microcefalia_zika_am

5. Mattar S, González M. Now is the time for Zika Virus. Rev.MVZ Córdoba. 2015;20(2):45114512. 